\title{
Phonological Variation and Prosodic Representation: Clitics in Portuguese-Veneto Contact
}

\author{
Natália Brambatti Guzzo \\ Lecturer, Department of Linguistics, McGill University, Montréal, \\ QC, Canada \\ nataliaguzzo@me.com
}

\section{Guilherme Duarte Garcia}

Assistant Professor, Department of English, Ball State University, Muncie, IN, USA

gdgarcia@bsu.edu

\begin{abstract}
In a variety of Brazilian Portuguese in contact with Veneto, variable vowel reduction in clitic position can be partially accounted for by the phonotactic profile of clitic structures. We show that, when phonotactic profile is controlled for, vowel reduction is statistically more frequent in non-pronominal than in pronominal clitics, which indicates that these clitic types are represented in separate prosodic domains. We propose that this difference in frequency of reduction between clitic types is only possible due to contact with Veneto, which, unlike standard BP, does not exhibit vowel reduction in clitic position. Contact thus provides speakers with the possibility of producing clitic vowels without reduction, and the resulting variation is used to signal prosodic distinctions between clitic types. We show that the difference in frequency of reduction is larger for older speakers, who are more proficient in Veneto and use the language regularly.
\end{abstract}

\section{Keywords}

clitic - prosodic representation - language variation - Brazilian Portuguese Veneto - contact 
In the variety of Brazilian Portuguese (BP) spoken in the region known as Italian Immigration Area (IIA), it has been observed that there is variation in the production of unstressed word-final vowels and clitic vowels (e.g., Frosi and Mioranza, 1983; Roveda, 1998; Vieira, 2002; Guzzo, 2012). In word-final and clitic positions, upper mid vowels [e, o] alternate with high vowels [I, 0$]$ (see (1b)). By contrast, in standard BP, vowel reduction is categorical both in clitic and final position (e.g., Câmara Jr., 1970; Bisol, 2000; Leite and Callou, 2002; see (1a)). In other words, while standard BP reduces its vowel system to three segments in word-final and clitic position $([\mathrm{a}, \mathrm{I}, \mathrm{J}])$, the IIA-BP system allows five segments in these positions $([\mathrm{a}, \mathrm{e} \sim \mathrm{I}, \mathrm{O} \sim \mathrm{J}])$. The preservation of upper mid vowels in these positions in IIA-BP is attributed to contact with Veneto (Frosi and Mioranza, 1983), where upper mid vowels in clitic and final position are not reduced.

(1) a. Standard BP:

$\begin{array}{ll}\text { /'tose/ } & \rightarrow[\text { 'tosi }] \\ / \text { 'bolo/ } & \rightarrow \text { 'bolo }] \\ / \text { me 'lavo/ } & \rightarrow[\text { mi 'lavo }] \\ / \text { do 'posto/ } & \rightarrow[\text { do 'post }]\end{array}$

'cough'

'cake'

'myself wash' (I wash myself)

'of the station'

b. IIA-BP:

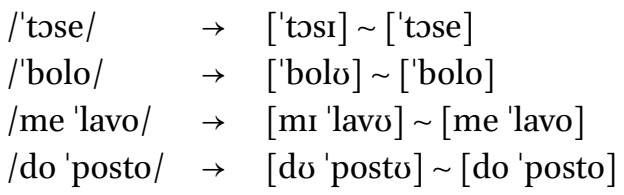

Sociolinguistic research has shown that variation in these positions in IIA-BP is constrained by segmental context (see e.g., Roveda, 1998; Vieira, 2002). For example, certain syllable onsets favour reduction, while others disfavour it. However, it has also been observed that a single clitic form corresponding to distinct syntactic categories (e.g., complementizer or pronoun) displays more or less reduction depending on its category. In particular, reduction targeting clitic se is more frequent when the clitic is non-pronominal (e.g., se chover if (it) rains') than when it is pronominal (e.g., se machuca 'she/he hurts herself/ himself'; Guzzo, 2012).

The question that arises is what constrains the phonological variation in this case, if not segmental context. Assuming that syntactic constructions are mapped onto a scale of prosodic domains where phonological processes apply (Nespor and Vogel, 1986; Selkirk, 1984, 1986), we propose that the variation is 
constrained by the prosodic relationship that the clitic holds with its host (the prosodically prominent word to which the clitic attaches). Specifically, when the clitic is syntactically freer, it will be adjoined to the host at a higher prosodic domain, where vowel reduction is expected to be more frequent. As pronominal and non-pronominal se have an otherwise identical phonological behaviour, the evidence for their distinct prosodic representation is manifested through the different frequency at which variable vowel reduction applies. We thus further propose that contact with Veneto provides IIA-BP speakers with an additional way of producing clitic vowels (i.e., without vowel reduction), and the resulting variation is used by these speakers to signal distinctions in prosodic representation.

In this paper, we use the term clitic to refer to non-prominent monosyllabic function words that associate with a prominent element (the host) in order to be instantiated (see, e.g., Zwicky, 1977, 1985; Nespor and Vogel, 1986; Selkirk, 1996; Anderson, 2005; Spencer and Luís, 2012). Thus, even though pronominal se and non-pronominal se have distinct syntactic distributions, they are similar in that their instantiation in BP relies on the existence of a prominent host to their right. We further assume that clitic structures do not have an $a$ priori prosodic representation crosslinguistically (following, e.g., Selkirk, 1996; Peperkamp, 1997; contra, e.g., Nespor and Vogel, 1986). Therefore, examination of the phonological behaviour of clitics, including gradual differences between types of clitics for a particular phonological process, contributes to a better understanding of the ways in which these elements can associate with their hosts across languages.

This paper is structured as follows. In Section 2, we describe the community where BP is in contact with Veneto. We then present the data as well as our statistical analysis. In Section 3, we compare the phonological behaviour of clitics with the behaviour of other unstressed positions, discuss the effects of frequency on prosodic representation, and propose separate prosodic structures for pronominal and non-pronominal clitics in IIA-BP. In Section 4, we show that the morphosyntactic behaviour of these clitics is consistent with their phonological behaviour and, consequently, with their prosodization in distinct domains. In Section 5, we explore the role of contact in the representation of IIA-BP clitics, as well as the possibility that IIA-BP has borrowed prosodic structures from Veneto. Finally, in Section 6, we offer some concluding remarks.

Sociolinguistic studies examining phonological variation in the IIA attribute the existence of variation in the area largely to contact with the local variety of 
Veneto (e.g., Roveda, 1998; Vieira, 2002; Battisti, 2004; Tomiello, 2005; Battisti et al., 2007; Mauri, 2008). Before we examine the variation in the production of clitic se in greater detail, we turn to a brief description of the community.

\subsection{The Italian Immigration Area}

The Italian Immigration Area in southern Brazil (Fig. 1) is the area in the state of Rio Grande do Sul where many Italian immigrants settled starting 1875 . Before immigration, the IIA was scarcely inhabited, with a few indigenous groups and Portuguese-speaking villages in its territory (Frosi and Mioranza, 1983, 2009; Souza, 2008).

The Italian population who settled in the IIA lived in relative isolation from Portuguese- and Hunsrückisch-speaking (Germanic) $)^{1}$ neighbouring communities, primarily due to difficulties in transportation and communication (De Boni and Costa, 1979). The vast majority of IIA immigrants were from Northern Italy, in particular from the Veneto region, which contributed to the development of a local variety of Veneto ${ }^{2}$ (Frosi and Mioranza, 1983).

Subsequent access to formal education, as well as improvement in communication and transportation systems, provided IIA residents with more contact with Brazilian Portuguese, especially in urban areas. The local Veneto variety has thus progressively been associated with rural areas and older speakers.

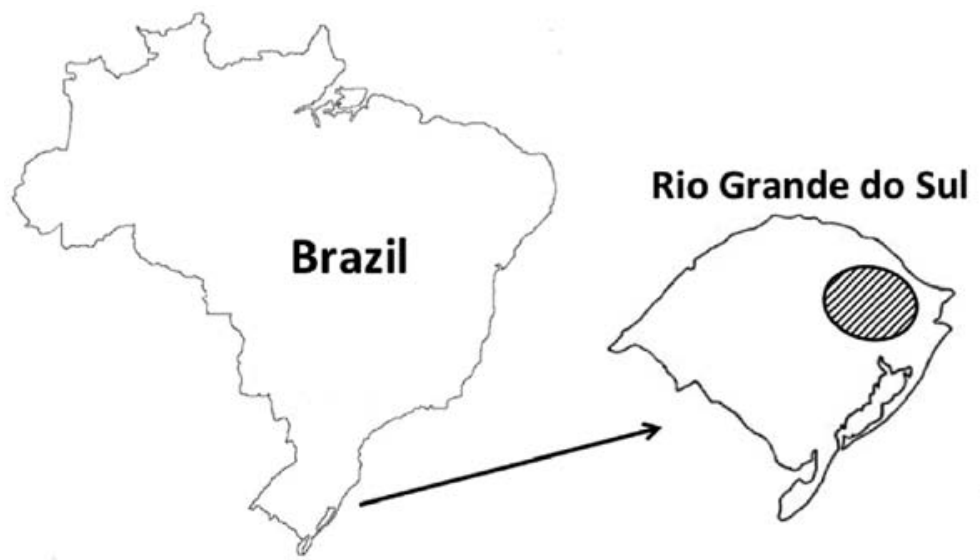

FIGURE 1 The Italian Immigration Area in southern Brazil

1 German immigration to southern Brazil preceded Italian immigration. As German immigrants were assigned to the flatlands and Italian immigrants were assigned to the highlands, contact between the two groups in the early years of Italian immigration was scarce (Frosi and Mioranza, 1983, 2009).

2 This variety is referred to in the literature (in linguistics or otherwise) simply as dialect, but it is also known locally as Talian. 
Nevertheless, contact with Veneto has influenced the variety of BP spoken in the IIA, in that features of Veneto are transferred to IIA-BP, particularly in the speech of older or rural individuals. For example, it is representative of IIA-BP the use of flap $[r]$ instead of vibrant $[r]^{3}$ (e.g., [r]ato 'rat', instead of [r]ato; see Frosi and Mioranza, 1983; Battisti, 2004), and the non-palatalization of /t, d/ before [i] (e.g., [t]ime 'team', instead of [ $\mathfrak{\mathrm { t }}$ ] $]$ ime; see Battisti et al., 2007; Mauri, 2008).

Additionally, IIA-BP is identifiable on the basis of the variable application of vowel reduction in word-final and clitic position ${ }^{4}$ (e.g., $\mathrm{m}[\mathrm{e}] \mathrm{lav}[\mathrm{o}]$ ' (I) wash myself', instead of $\mathrm{m}[\mathrm{I}] \operatorname{lav}[\mho]$ ), with the preservation of upper mid vowels attributed to contact with Veneto (Frosi and Mioranza, 1983). Sociolinguistic studies on vowel reduction in IIA-BP have found that variation in such positions can be partially explained based on segmental context, in that reduction may be favoured or disfavoured by certain segments adjacent to the target vowel (e.g., Roveda, 1998; Vieira, 2002). For example, while preceding alveolar stops $(/ t, d /)$ in open syllables disfavour vowel reduction, a preceding alveolar fricative /s/ or velar stop / $\mathrm{k} /$ favour it. Despite the effect of segmental context on reduction, other observations with regard to the application of this process seem to require a different explanation.

Specifically, it has been noted that a single clitic form can exhibit vowel raising more or less frequently depending on its syntactic category (Guzzo, 2012). This is the case of clitic se, which can be pronominal and non-pronominal. The examples in (2) illustrate the distribution of pronominal and non-pronominal $s e$ (in both standard BP and IIA-BP). In IIA-BP, vowel reduction appears to apply more frequently in non-pronominal se (Guzzo, 2012).

(2) 'se' as a pronominal clitic:

a. reflexive/reciprocal

$\begin{array}{lll}\text { Ele } & \text { se } & \text { cortou } \\ \text { he } & \text { REFL } & \text { cut.PST }\end{array}$

'He cut himself.'

3 In current standard $\mathrm{BP},[\mathrm{r}]$ is usually produced as [x].

4 It should be noted that vowel reduction in word-final and clitic position are not subject to the same prosodic constraints in BP. On one hand, both are neutralization processes, in that the contrast between upper mid and high vowels, which is observed in primarily stressed syllables, is eliminated in clitic and unstressed word-final positions (see Câmara Jr., 1970; Wetzels, 1992). On the other hand, while word-final reduction is constrained by the position of primary stress in the word, reduction in clitic positions applies as a consequence of the clitic being prosodically weak (see Bisol, 2000, 2005; Vigário, 2003). We refer to both phenomena as vowel reduction so as to illustrate the observation that certain unstressed positions in BP undergo weakening processes. 
b. impersonal

Se trabalha muito

IMPER work.PRS a.lot

'One works a lot.'

c. passive

$\begin{array}{lll}\text { Se vendeu bastante } & \text { uva } \\ \text { PASs sell.PST a.lot.of } & \text { grape } \\ \text { 'A lot of grapes were sold.' } & \end{array}$

'se' as a non-pronominal clitic:

d. complementizer in an embedded content clause

$\begin{array}{lllll}\text { Ele } & \text { perguntou } & \text { se } & \text { vocês } & \text { vêm } \\ \text { he } & \text { ask.PST } & \text { if } & \text { you } & \text { come.PRS }\end{array}$

'He asked if you are coming.'

e. complementizer in an embedded adverbial clause

$\begin{array}{llll}\text { se voce } & \text { vier, } & m e & \text { telefone } \\ \text { if you } & \text { come.sBJV } & \text { me } & \text { call.IMP }\end{array}$

Segmental context does not appear to account for the difference in frequency of vowel reduction between pronominal and non-pronominal $s e$, as the process does not seem to be influenced by the segment following the clitic vowel or the quality of the vowel of the following syllable (see, e.g., Guzzo, 2010 and the data analysis in next section). It thus appears that the difference in vowel raising between pronominal and non-pronominal se is constrained by another factor. We propose that this difference between pronominal and non-pronominal se arises from distinctions in the prosodic representation of these clitics. Before we discuss how clitics are represented in the IIA-BP grammar, we turn to an analysis of empirical data in order to examine whether the previous observations about frequency of vowel reduction in pronominal and non-pronominal se can be statistically confirmed. Since this case of variation is in a context of language contact, it is possible that it is further constrained by elements associated with contact in the IIA, such as the age of the speakers and their place of residence.

\section{$2.2 \quad$ The Data}

The data discussed in this section were obtained from sociolinguistic interviews ${ }^{5}$ performed in the IIA municipality of Flores da Cunha. Flores da Cunha

5 These interviews are part of a database of sociolinguistic interviews called Banco de Dados de Fala da Serra Gaúcha (BDSer), coordinated by Prof. Elisa Battisti and hosted at Universidade de Caxias do Sul, in Caxias do Sul, Brazil (Battisti and Lembi, 2004). 
is a small town (population 26,00o) that is representative of the IIA: the majority of its population is of Northeastern Italian descent, its urban and rural areas are well delimited, and the social practices associated with Italian immigration are preserved (e.g., Tomiello, 2005; Mauri, 2008). Participants were selected based on sex (2 groups), age (4 groups: 18-30 years old, 31-50 yo, 51-70 yo, and $71+$ yo), and place of residence ( 2 groups: urban and rural). There are two participants per cell combination, resulting in a total of $3^{2}$. These data were originally part of a sociolinguistic analysis of variable vowel reduction in which all unstressed positions were considered (initial, medial pre-stress, final, non-final post-stress, and clitic; Guzzo, 2010). In a subsequent examination (Guzzo, 2012), the instances of clitic se were classified as pronominal and non-pronominal, given that this clitic form can correspond to both categories (see the examples in (2) above).

The older speakers in our sample (in the $5^{1-70}$ yo and $71^{+}$yo groups) describe themselves as being bilingual in Portuguese and Veneto. The majority of speakers who live in the rural area also report being bilingual, regardless of their age, even though rural speakers from the younger age groups report using Veneto less frequently than speakers in the older age groups. Speakers in the $71+$ yo group are those who reportedly use Veneto on a regular basis, especially with family members and other individuals from the same age group. Some of the individuals in the younger groups and who live in the urban area also report being able to understand Veneto or even speak it (at different degrees), but they do not use it (or listen to it) frequently. Given that bilingualism in the community is strongly correlated with age and place of residence, degree of bilingualism was not included in the statistical analysis as a predictor.

For the present analysis, we selected all the occurrences $(n=713)$ of pronominal and non-pronominal se included in Guzzo $(2010,2012)$. Examination of the individual tokens in Guzzo (2010) enabled us to incorporate more items which had previously been miscoded or not included in the analysis $(n=115)$. Both authors then listened to all the recordings in order to double check the previous coding for category (pronominal or non-pronominal) and absence/ presence of vowel reduction. The resulting total number of tokens is 828 (445 pronominal, 383 non-pronominal).

A representative sample of the total number of tokens (approx. 30\%) was then phonetically analysed in Praat (Boersma and Weenink, 2020) to confirm that the formant patterns of such tokens were consistent with their categorical coding. Figure 2 plots $\mathrm{F}_{1}$ and $\mathrm{F}_{2}$ values for the vowels in our sample. Vowels coded as reduced have in effect a lower F1 overall: Mean $\hat{\beta}=-118,95 \%$ highest density interval $(\mathrm{HDI})=[-249.30,10.97] \cdot{ }^{6}$ Likewise, vowels coded as reduced

6 F1 and F2 were modelled with Bayesian linear regressions in R (R Core Team, 2018) using Stan (Carpenter et al., 2017). Because results are distributions, and because the distributions here 


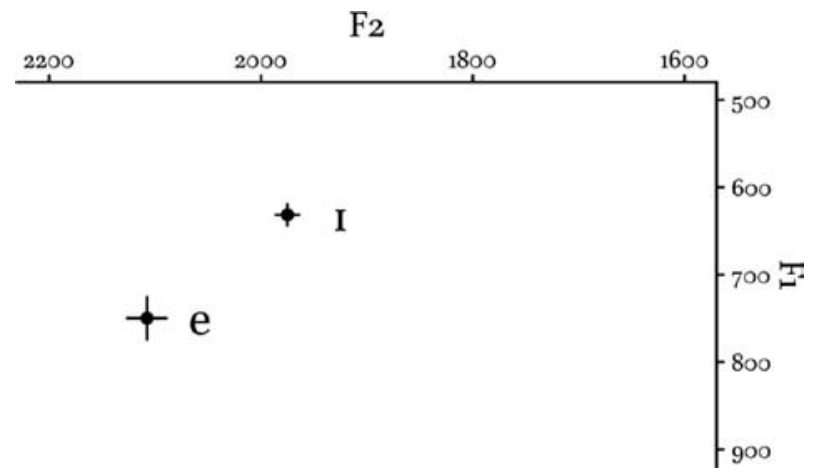

FIGURE 2 F1 and $\mathrm{F}_{2}$ values for reduced and non-reduced clitic vowels. Means and standard errors from the means $\left(\mathrm{F} 1\right.$ and $\left.\mathrm{F}_{2}\right)$ are provided

have a lower F2: Mean $\hat{\beta}=-134,95 \%$ HDI $=[-244.39,-27.62]$. These findings are consistent with the observation that upper mid vowels that undergo reduction in unstressed positions undergo raising and centralization (see, e.g., MassiniCagliari, 1992). ${ }^{7}$

With respect to linguistic variables, the tokens were coded based on type of clitic (pronominal or non-pronominal), following segmental context (the segment that immediately followed the clitic vowel), and following vowel (the quality of the vowel in the syllable that followed the clitic). The coding also accounted for extralinguistic variables, namely, sex, age group, and place of residence of the speakers. Table 1 lists all the predictor variables that were controlled for, as well as the response variable.

Overall, we predict that reduction should be statistically more frequent in non-pronominal than in pronominal se. That is because non-pronominal se is

are assumed to be Gaussian, Mean $\hat{\beta}$ describes the most probable value for the difference in F1 and F2 given the data. 95\% highest density intervals are probability distributions (cf. confidence intervals): values which are closer to the peak of the distribution are more probable given the data. Note that the posterior distribution of credible values of $F_{1}$ is almost entirely negative.

7 It should be noted that the observation that reduced vowels in unstressed positions are centralized has been made mainly based on the behaviour of the mid back vowel /o/: in final unstressed position, it reduces to $[\mho]$ and is significantly more centralized than stressed $[\mathrm{u}]$. No statistical differences in $\mathrm{F}_{1}$ and $\mathrm{F} 2$ between stressed [i] and [r] in unstressed final position have been observed (Massini-Cagliari, 1992). However, previous studies have not explored the quality of clitic vowels. 
TABLE $1 \quad$ Response and predictor variables

Response variable: Reduction (1) vs. no reduction (o)

Predictor variables: Clitic type (TYPESE)

Following vowel (FVowEL)

Following context (FCONTEXT)

SEX

Age group (AGE)

Place of Residence

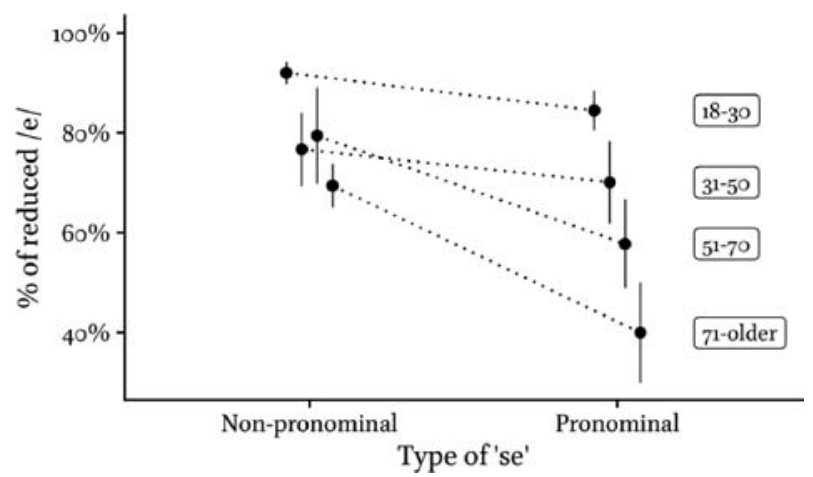

FIGURE 3 Overall responses by clitic type and age: mean percentages of reduction and standard errors

more independent syntactically, while pronominal $s e$ is bound to its verb host, in a way comparable to a prefix (see Section 4). We also predict that this difference in the application of reduction should be more salient in the speech of older, rural speakers, since these are the groups that consistently display reduction less frequently in contexts where reduction is obligatory in standard BP (see, e.g., Roveda, 1998). Younger, urban speakers, who have been increasingly abandoning Veneto-related processes in their BP speech, may display categorical reduction in both pronominal and non-pronominal clitics, thus mirroring what is observed in standard BP.

Figure 3 shows the proportions of reduction by clitic type and age. The average proportions of reduction were $79.4 \%(s=19.5 \%)$ for non-pronominal $s e$, and $63.8 \%(s=26.7 \%)$ for pronominal $s e$. Consistent with our predictions, 
reduction is overall more frequent with non-pronominal se than with pronominal $s e$ - the mean percentage of reduction is always higher for non-pronominal $s e$ in the figure. Likewise, the age group where the difference between clitic types is the most noticeable is the older age group - denoted by the steepest dotted line between non-pronominal and pronominal se. In contrast, the difference observed for the younger groups (18-30 yo and 31-50 yo) is less substantial.

The data were modelled using Bayesian mixed-effects logistic regression (R Development Core Team, 2018) with REDUCTION (reduced vs. non-reduced) as the response variable. Using stepwise selection, the predictor variables included in the model were clitic type (TYPESE), following vowel (FVOWEL), SEX, AGE GROUP, and PLACE OF RESIDENCE. The model included a by-speaker random intercept and a by-speaker random slope for TYPESE, which take into account the overall variation among speakers and the variation among speakers by clitic type, respectively. Overall, the effect of pronominal se is consistent across participants: all by-speaker posterior distributions have a negative mean, which indicates that they consistently disfavour reduction in pronouns (see Fig. 12 in the appendix). Figure 4 shows the main effects of the statistical model.

These results confirm that vowel reduction is statistically less frequent in pronominal $s e$, whose odds of reduction go down by a factor of $2.65\left(e^{0.98}\right)$. The odds of reduction also go down as the age of the speakers increases, as can be seen by the negative estimates in Fig. 4: the oldest group of speakers has the lowest effect size (Mean $\hat{\beta}=-2.21$ ), which indicates that this group is the least favourable to reduction. As we move up the figure towards younger speakers, the effect size shifts rightward, indicating that younger speakers are more favourable to reduction - note that all three age groups shown are compared to the youngest speaker group, 18-30 yo (intercept). The 95\% HDI for SEX, PLACE OF RESIDENCE, and FVOWEL:MID all clearly include zero as a credible value. This indicates that the effect of these predictors is less statistically credible than, for example, the effect of pronominal se given the data modelled. FVowEL:HIGH shows a credible negative effect, which indicates that reduction is dispreferred when the vowel of the following syllable is high. We discuss this result in the next section.

The fact that pronominal and non-pronominal se behave statistically differently with respect to reduction cannot be explained based on segmental context, given the model in question. We thus propose that the difference in frequency of vowel reduction between non-pronominal and pronominal se stems from distinctions in their prosodic representation. In the next section, 


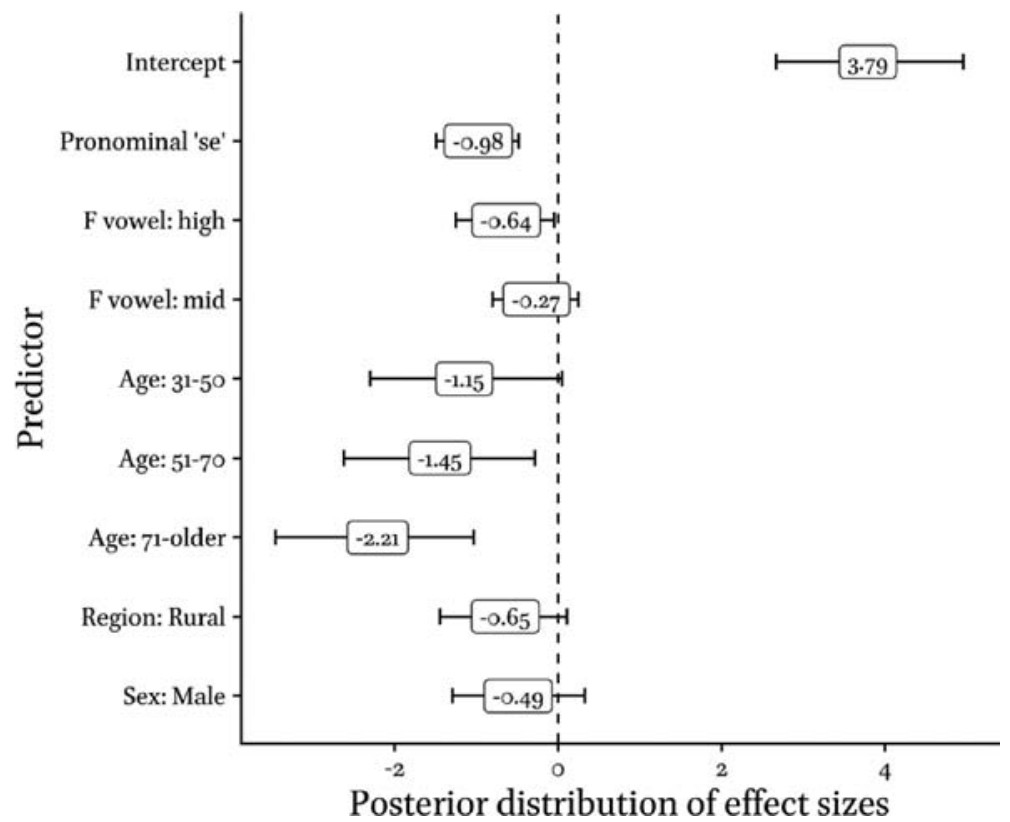

FIGURE 4 Statistical model results:

Y-axis shows the posterior distributions of credible effect sizes given the data. Negative effects indicate that reduction is disfavored. All effects must be interpreted relative to the intercept, which represents non-pronominal se, a low vowel in the following syllable (/a/), and 18-30 yo female speakers with an urban place of residence. Error bars display the $95 \%$ highest density interval: values within the interval are more likely than values outside the interval given the data. Mean effect sizes (in log-odds) are provided in the boxes

we discuss the phonological behaviour of pronominal and non-pronominal clitics in IIA-BP in order to determine in which domain their prosodization occurs. We reserve the discussion on the role of contact in the prosodization of IIA-BP clitics for Section 5 .

The data presented in the previous section indicates that vowel reduction applies statistically more frequently in non-pronominal than pronominal clitics in IIA-BP. The statistical model showed little or no statistically credible effect of phonological environment, which can be observed in the posterior distributions of FVOWEL in Fig. 4, as well as in the absence of following segmental 


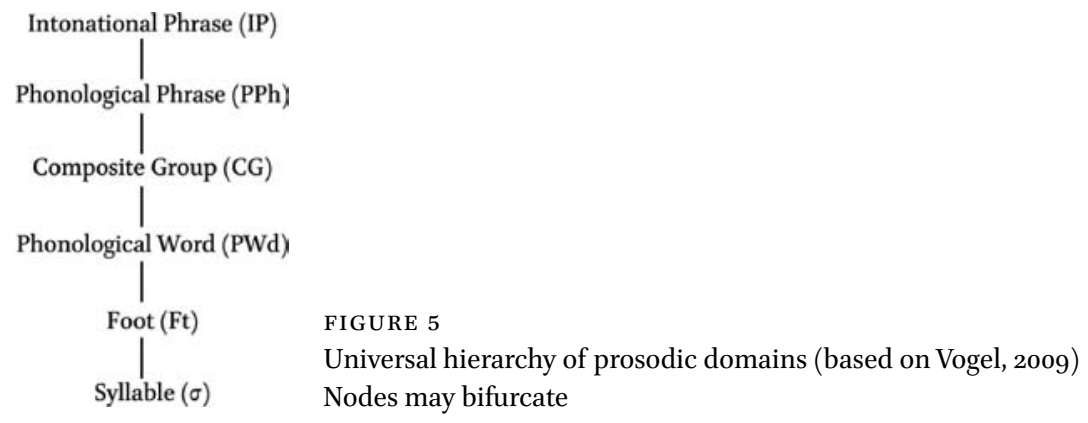

context as a relevant predictor in our stepwise selection. This indicates that reduction in clitic se cannot be explained solely by phonotactic factors. The alternative possibility is that vowel reduction in this position is constrained by prosodic structure. Under this view, differences in phonological behaviour between pronominal and non-pronominal clitics are a consequence of their mapping onto distinct prosodic domains.

Prosodic domains, which correspond to the domains where phonological processes apply, are the result of indirect mapping from syntax (Selkirk, 1984, 1996, 2011; Nespor and Vogel, 1986; Hayes, 1989; Inkelas, 1990). The organization of such domains into a scale (or prosodic hierarchy) prevents that processes that are specific to a particular domain overapply in other domains. As a result, linguistic constructions can be identified as belonging to a given domain on the basis of the phonological processes that they exhibit. Figure 5 shows the prosodic hierarchy.

We propose that pronominal and non-pronominal clitics behave differently with respect to the frequency of application of vowel reduction because they are mapped onto distinct prosodic domains. We thus assume that prosodic domains constrain not only the application of categorical phonological processes, but also the frequency at which variable phenomena apply. The assumption that prosodic domains can display frequency effects in process application is not a claim that is particular to the present study. A proposal along these lines has been advanced by Vigário (2003) to account for differences in the frequency of vowel reduction in European Portuguese (EP) clitic de 'of, from', which can function as either a complementizer or a preposition. Vigário (2003) observed that preposition de undergoes reduction more frequently than complementizer de, which suggests that, given EP's specific reduction patterns, 
preposition de adjoins its host at a lower prosodic domain than complementizer $d e .^{8}$

Before we discuss the prosodic representation of pronominal and nonpronominal se based on vowel reduction frequency, it is necessary to establish which prosodic domains can potentially accommodate clitic structures in (IIA-)BP. To do so, we first compare the phonological behaviour of these clitics with the behaviour of other pretonic positions. We start by examining wordinternal pretonic vowels. If pronominal or non-pronominal clitics pattern with pretonic vowels, this would indicate that clitic prosodization may occur within the phonological word (PWd).

\subsection{Clitics and Word-internal Pretonic Vowels}

Vowel reduction is not a property of clitics and unstressed word-final positions. Previous studies have observed that, across varieties of BP (including IIA-BP), upper mid vowels /e, o/ variably raise to [i, u] in pretonic positions when there is a high vowel in the following syllable ${ }^{9}$ (e.g, Bisol, 1981; Oliveira, 1992; Battisti, 1993; Schwindt, 2002; see 3). This phenomenon is traditionally referred to in the literature as BP Vowel Harmony (see, e.g., Bisol, 1981).

$\begin{array}{lllll}\text { a. } & \text { /se'g[u]nda/ } & \rightarrow & \text { [si'gũnde }] & \text { 'second' } \\ \text { b. } & \text { /pe'rigo/ } & \rightarrow & {[\text { pi'rigo }]} & \text { 'danger' } \\ \text { c. } & \text { /bo'nito/ } & \rightarrow & \text { [bu'nito }] & \text { 'beautiful' } \\ \text { d. } & \text { /ko'ruza/ } & \rightarrow & \text { [ku'ruze }] & \text { 'owl' }\end{array}$

It should be noted that the quality of the vowel resulting from reduction is distinct in pretonic and clitic position $([\mathrm{i}, \mathrm{u}]$ in pretonic position vs. $[\mathrm{I}, \mathrm{U}]$ in clitic position; see, e.g., Massini-Cagliari (1992) and Fig. 2). Thus, while both clitic and pretonic vowels pattern together in that they can undergo reduction, the phonetic result of reduction is different depending on its position, which is

8 As will be shown in the remainder of this section, vowel reduction in BP is associated with adjunction to higher domains of the prosodic hierarchy, which might seem to contradict Vigário's analysis for clitic de in European Portuguese. However, EP and BP pattern differently with regard to vowel reduction. In EP, vowel reduction is expected in all word-internal unstressed positions (see e.g., Mateus and d'Andrade, 2000). In standard BP, on the other hand, vowel reduction within the word domain is categorical only word-finally, and it is highly constrained in other unstressed positions. Section 3.1 further discusses word-internal vowel reduction in BP.

9 Reduction in this position is also constrained by lexical factors; for example, certain word families are more likely to display reduction in pretonic position, even if there is no high vowel in the following syllable (Oliveira, 1992; Bisol, 2009). 
an indication that clitic and pretonic vowels in fact undergo distinct processes. Nevertheless, it could be the case that reduction in clitic and pretonic position is constrained by identical factors, if, for example, reduction in clitics were also conditioned by a following high vowel.

The effect of the following vowel was accounted for in the statistical model by the predictor FVOWEL. The effect of a high vowel in the following syllable was found to be statistically credible, although weak if compared to the effect of pronominal se (see Fig. 4). However, such an effect is not in the expected direction considering the vowel harmony data above: when the vowel in the syllable that follows the clitic is high, reduction is less likely to apply. Reduction in clitic se thus appears dissimilatory, unlike what is observed in pretonic position.

However, the data presented here is not sufficient for us argue for dissimilatory effects that target the entire class of IIA-BP clitics, given that only one clitic form (and only one target vowel) were examined. It should be noted, though, that the fact that a following high vowel does not have a positive effect in the model suggests that reduction in clitic position is not vowel harmony and, therefore, clitic vowels do not pattern with pretonic vowels in IIA-BP. Specifically with regard to prosodic representation, the harmony data suggest that lexical items where pretonic vowels undergoing harmony are part of the stem (such as in the examples in (3)) correspond to simple phonological words (PWds; see Fig. 6).

According to this representation, vowel harmony is a PWd process, and its non-application in clitic position implies that clitic adjunction to a host must occur in a domain other than the PWd. An alternative is that clitics' phonological behaviour is comparable to the behaviour of unstressed monosyllabic prefixes, which, as will be discussed below, do not seem to incorporate into the PWd projected by the stem. We examine this possibility in the next subsection.

\subsection{Clitics and Monosyllabic Prefixes}

Clitics and monosyllabic prefixes have several similarities: both are unstressed and attach to a fully-formed PWd. Portuguese, including IIA-BP, also has stressed prefixes (e.g., pré in pré-escola 'pre-school'), as well as unstressed prefixes that belong to circumfixed constructions (e.g., en in en-lat-ado 'canned

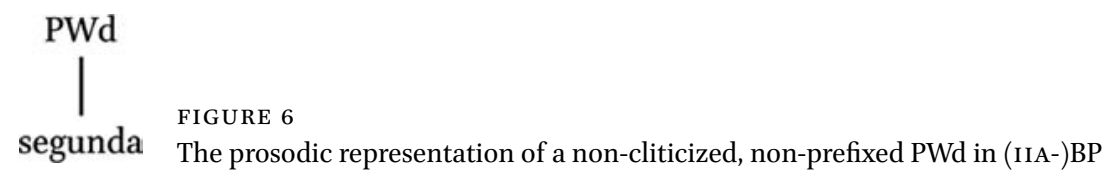


(n or adj)'; *enlata (n), *latado) and unstressed prefixes in lexicalized constructions (i.e., where the boundary between the prefix and the host is opaque; e.g., pre in preâmbulo 'preamble'; see, e.g., Schwindt, 2001; Toneli, 2014; Guzzo, 2018). These prefixes, however, will not be analysed here since the constructions that they form with their hosts are not comparable to clitic + host structures due to differences in stress assignment (in the case of stressed prefixes) or in the relationship between the prefix and the host (in the case of prefixes in circumfixed constructions or lexicalized constructions).

It has been shown that unstressed monosyllabic prefixes do not behave in a uniform way with respect to vowel reduction. While a prefix such as des- seems to undergo vowel reduction across BP varieties (including IIA-BP; see Battisti, 1993), reduction in prefix re-seems to be blocked (see (4)).

(4) Prefix + host structures:
a. des + fazer $\rightarrow$ [dुzis]-fazer ${ }^{10}$
'to undo'
b. re + fazer $\rightarrow$ r[e]-fazer $\left(\mathrm{cf} .{ }^{*} \mathrm{r}[\mathrm{i}]\right.$-fazer $)$
'to redo'

The distinction in phonological behaviour between these two prefixes can be partially accounted for by phonotactic environment. It has been shown that, in $\mathrm{BP}$, there is a tendency to reduce (and delete) unstressed mid/high front vowels when they are preceded by an alveolar stop and followed by a sibilant (e.g., Bisol, 1991; see (5)).
a. medi'sine $\sim$ medzii'sine $\rightarrow$ med'sine 'medicine'
b. 'ẽntes $\sim$ 'ẽntf $\widehat{\text { Is }}$
'before'
c. des-fa'zer $\sim$ đ̧̧is-fa'zer $\rightarrow$ ds-fa'zer
'to undo'

As vowel reduction in pronominal and non-pronominal se is not phonotactically conditioned, it would not be reasonable to compare the phonological behaviour of this clitic (and clitics in general) with the behaviour of an unstressed prefix for which reduction is phonotactically determined. We turn then to prefix $r e$-, which is one of the few productive unstressed prefixes with an upper mid vowel in BP.11 As mentioned above, the vowel in prefix re- does not reduce in BP varieties. It has been argued, however, that reduction can variably apply if the first syllable of the host contains a high vowel (e.g., Schwindt, 2001; see (6a)). While this may be the case for some BP varieties, it is not what

\footnotetext{
$10 \quad$ Alveolar stops $/ t, d /$ are palatalized before high front vowels (resulting in [ $\left[\widehat{t}\right.$, $\left.\widehat{d}_{3}\right]$ ) in most $\mathrm{BP}$ varieties. This process is variable in IIA-BP.

11 Prefix $\mathrm{co}^{-}$, with an upper mid back vowel, has a similar phonological behaviour to re-
} 
is observed in IIA-BP, where reduction in prefix re- is not attested (see (6b)). Note that, in the examples in (6a), there is uncertainty with regard to whether reduction would apply systematically whenever there is a high vowel in the following syllable, or whether it would be constrained to specific lexical items (such as re-fiz) instead.

(6) a. Possible reduction in prefix re- in some BP varieties (including standard BP):

$\begin{array}{llll}\text { re-fiz } & \rightarrow & \text { r[i]-fiz } & \text { '(I) re-did' } \\ \text { re-li } & \rightarrow & \text { ?r[i]-li } & \text { '(I) re-read' } \\ \text { re-pus } & \rightarrow & \text { ?r[i]-pus } & \text { '(I) re-put' } \\ \text { re-disse } & \rightarrow & \text { ?r[i]-disse } & \text { '(I) re-said' }\end{array}$

b. No reduction in prefix re- in IIA-BP:

re-fiz $\rightarrow$ r[e]-fiz, ${ }^{*} r[i]-f i z$

re-li $\rightarrow \quad r[e]-l i,{ }^{*} r[i]-l i$

re-pus $\rightarrow \quad r[\mathrm{e}]$-pus, ${ }^{*} \mathrm{r}[\mathrm{i}]$-pus

re-disse $\rightarrow \mathrm{r}[\mathrm{e}]$-disse, ${ }^{*} \mathrm{r}[\mathrm{i}]$-disse

The behaviour of unstressed monosyllabic prefixes thus differs from the behaviour of clitics with respect to vowel reduction. Nevertheless, it could still be the case that clitics and unstressed prefixes pattern together for another phonological phenomenon in BP, which could in turn be an indication that the non-application of reduction in unstressed prefixes is not a consequence of the domain where prefix + host structures are prosodized, but instead an effect of the nature of the morphological boundary between the prefix and the host. The examination of vowel juncture processes can potentially answer this question, since both clitic constructions and prefix + host structures provide environment for such processes to apply.

BP exhibits three variable vowel juncture processes: diphthongization (a high vowel becomes a glide when followed by a non-high vowel), degemination (a vowel deletes when followed by an identical vowel), and elision (a vowel deletes when followed by a non-identical vowel; e.g., Abaurre, 1996; Tenani, 2002; Bisol, 2003; Gayer, 2014). Since elision usually targets the vowel /a/, and no unstressed monosyllabic prefix has such vowel, we will focus solely on diphthongization and degemination. The data presented in the remainder of this subsection is representative of most BP varieties, including IIA-BP.

Diphthongization applies in structures with both pronominal and nonpronominal clitics (Bisol, 2000, 2005). The examples in (7) indicate that, for 
diphthongization to apply, the clitic vowel needs to reduce. Diphthongization targets both front and back high vowels, as illustrated in the examples in (7).

(7) Pronominal clitics:

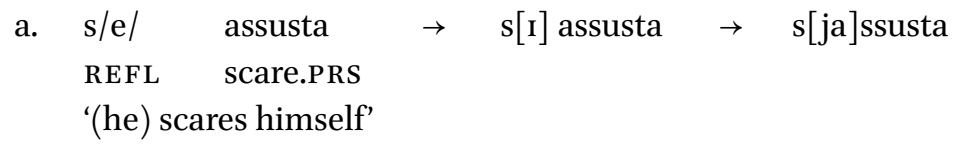

Non-pronominal clitics:
b. s/e/ assustar $\rightarrow \mathrm{s}[\mathrm{I}]$ assustar $\rightarrow \mathrm{s}[\mathrm{ja}]$ ssustar if $\quad$ scare.sBJv 'if (he) scares (someone)'
c. d/o/ amigo $\rightarrow \mathrm{d}[\mho]$ amigo $\rightarrow \mathrm{d}[$ wa $]$ migo of.the friend 'of the friend'

Vowels in unstressed monosyllabic prefixes, on the other hand, do not display diphthongization (see (8)). This is a consequence of the non-application of reduction in prefixes: since upper mid prefix vowels cannot reduce to high, diphthongization is blocked from applying. As the examples in (8) show, a hiatus is maintained in prefix + host structures where the host starts with a nonhigh vowel.

(8) re-animar $\rightarrow{ }^{*} \mathrm{r}[\mathrm{ja}]$ nimar, $\mathrm{r}[\mathrm{ea}]$ nimar $\quad$ to reanimate' re-ocupar $\rightarrow \quad$ *r[jo]cupar, $\mathrm{r}[\mathrm{eo}]$ cupar $\quad$ 'to re-occupy'

Clitic vowels also undergo degemination variably (Bisol, 2000, 2005). In BP varieties where vowel reduction is categorical in clitic position, degemination is only observed when the host starts with a high vowel that is identical to the clitic vowel. ${ }^{12}$ In IIA-BP, since reduction in clitic position is variable, degemination is also observed when the clitic vowel is followed by an identical upper mid vowel (see (9)).

(9) Degemination in most BP varieties:
a. $\mathrm{s}[\mathrm{I}] \quad[\mathrm{i}]$ squeceu $\rightarrow \mathrm{s}[\mathrm{i}]$ squeceu
REFL forget.PST
'he forgot' ( $s e=$ pronominal clitic)

12 Degemination is blind to the tenseness of the high vowels involved. 
b. $\mathrm{s}[\mathrm{I}] \quad$ [i]studar $\rightarrow \mathrm{s}[\mathrm{i}]$ studar

if study.sBJv

'if (he) studies' ( $s e=$ non-pronominal clitic)

Degemination in IIA-BP:

c. $\mathrm{s}[\mathrm{I}] \quad[\mathrm{i}] \mathrm{squeceu} \rightarrow \mathrm{s}[\mathrm{i}]$ squeceu

REFL forget.PST

'he forgot' ( $s e=$ pronominal clitic)

d. $\mathrm{s}[\mathrm{e}] \quad[\mathrm{e}]$ legeu $\rightarrow \mathrm{s}[\mathrm{e}]$ legeu

REFL elect.PST

'he got elected' ( $s e=$ pronominal clitic)

e. $\mathrm{s}[\mathrm{I}] \quad[\mathrm{i}]$ studar $\rightarrow \mathrm{s}[\mathrm{i}]$ studar

if study.sBJV

'if (he) studies' ( $s e=$ non-pronominal clitic)

f. $\mathrm{s}[\mathrm{e}] \quad[\mathrm{e}]$ leger $\rightarrow \mathrm{s}[\mathrm{e}] \mathrm{leger}$

if elect.sBJv

'if (he) elects' ( $s e=$ non-pronominal clitic)

It has been argued that degemination in sequences of unstressed monosyllabic prefix + host is possible (Bisol, 200o). However, it appears that the process is observed only in lexicalized expressions, that is, in prefix + host constructions whose meaning is not a sum of the meaning of their parts (see (10a) and (10b)). In cases where the meaning of the prefix + host construction is transparent, degemination is blocked (see (1oc) and (1od)).

(10) Degemination with non-transparent prefixes:
a. re-estabelecer $\rightarrow \mathrm{r}[\mathrm{e}]$ stabelecer
'to recover'
b. co-operar $\rightarrow \mathrm{c}[\mathrm{o}]$ perar
'to help'

Degemination blocked with transparent prefixes:

c. re-estabelecer $\rightarrow \mathrm{r}[$ ee $]$ stabelecer $\sim \mathrm{r}[$ ej] stabelecer 'to re-establish'

d. co-operar $\rightarrow \mathrm{c}[\mathrm{oo}]$ perar $\quad$ 'to co-operate' (i.e., 'to operate together')

The data for vowel reduction and vowel juncture processes discussed in this subsection indicate that clitics and unstressed monosyllabic prefixes are not prosodized the same way. We propose that unstressed monosyllabic prefixes are recursively prosodized in the PWd (following, e.g., Schwindt, 2001, 2008; Guzzo, 2018; see Fig. 7). This representation is consistent with the fact that 


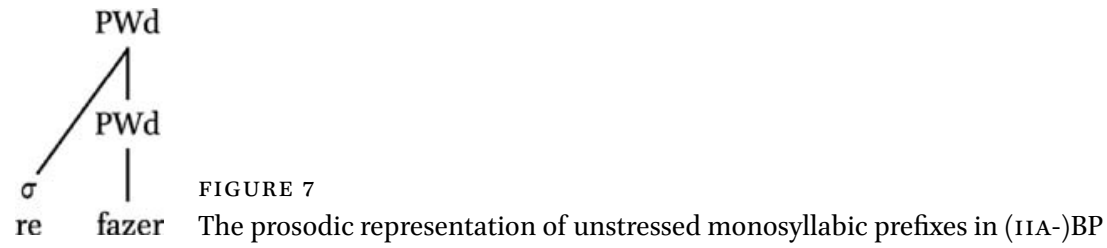

these prefixes do not exhibit vowel reduction (to [I, $]$ ) like clitics, which is an indication that they pattern with upper mid vowels found in pretonic position. The fact that vowel harmony is not observed in these prefixes motivates the proposal that there is a prosodic boundary between the prefix and its host.

Since clitics and unstressed monosyllabic prefixes behave differently with respect to both vowel reduction and vowel juncture processes, we assume that the representation in Fig. 7 is not adequate for the representation of clitics (either pronominal or non-pronominal) in IIA-BP. Given the prosodic hierarchy in Fig. 5, we now only have two domains where these clitics could be prosodized: the composite group (CG) or the phonological phrase $(\mathrm{PPh})$. The intonational phrase (IP) is not a viable option since this domain is usually associated with the assignment of intonational patterns, not the application of segmental processes. In the next subsection, we explore these two possibilities, by (a) examining previous proposals on clitic prosodization in BP, and (b) discussing the differences in frequency of vowel reduction between pronominal and non-pronominal $s e$ in IIA-BP.

\subsection{The Place of IIA-BP Clitics in the Prosodic Hierarchy}

As previously mentioned, vowel reduction in clitic position is obligatory in standard BP. With regard to vowel juncture processes, we have seen that diphthongization and degemination variably apply in clitic position, targeting both pronominal and non-pronominal clitics. Even though we do not have data on potential differences between pronominal and non-pronominal clitics for the frequency at which juncture processes apply, the observations discussed in the previous subsections seem to indicate that the two types of clitics have equivalent phonological behaviour in standard BP. Given that prosodic phonology is grounded on the assumption that prosodic structure can only be identified based on the phonological processes exhibited by linguistic constructions, it would be reasonable to propose that, in standard BP, pronominal and nonpronominal clitics have the same prosodic representation.

Previous analyses have indeed posited a single representation for clitic structures in BP. The crucial difference between these analyses is which 

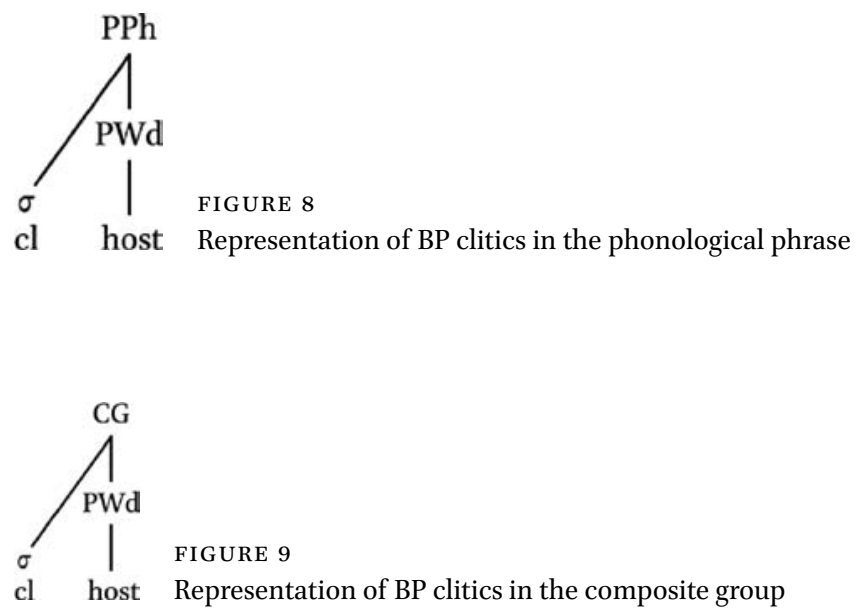

prosodic domain is assumed as the domain for clitic prosodization, given the phonological differences between clitics, pretonic syllables and unstressed prefixes presented above. The domain to which clitics have been assigned was influenced by specific views on the design of the prosodic hierarchy. Analyses that do not include a domain between the PWd and the phonological phrase (PPh; following, e.g., Inkelas, 1990; Selkirk, 1996) propose that clitic prosodization in BP occurs at the PPh (e.g., Simioni, 2008; see Fig. 8). On the other hand, analyses that assume the existence of a domain between the PWd and the PPh (following, e.g., Nespor and Vogel, 1986; Hayes, 1989; see also Vogel, 2008, 2009, 2010; Vigário, 2010) propose that BP clitics are prosodized in this intermediate domain (e.g., Bisol, 2000, 2005; see Fig. 9). Following Vogel (2008, 2009, 2010), we will refer to this domain as the composite group (CG) in our analysis.

Analyses that argue that the prosodization of BP clitics occurs at an intermediate domain between the PWd and the PPh, such as Bisol (2000, 2005), consider that this domain corresponds to the clitic group (proposed in Nespor and Vogel, 1986; Hayes, 1989). In initial accounts of prosodic phonology, the clitic group was constrained to a model of prosodic hierarchy which allowed neither domain skipping nor domain recursion. Given these constraints, clitics - which are by definition non-prominent - would necessarily have to correspond to PWds in order to be prosodized in the clitic group. Reactions to this view, as well as subsequent observations that clitics can behave in various ways with respect to their hosts (e.g., Selkirk, 1996; Peperkamp, 1997), led to the elimination of the clitic group from the prosodic hierarchy. Recent studies, however, have shown that a prosodic hierarchy without a domain between the 
PWd and the PPh is not capable of accounting for the patterns of certain clitic and compound structures (Vogel, 2008, 2009, 2010), and the CG (composite group) was proposed as the domain to occupy this position. The fundamental difference between the old clitic group and the CG is that the CG is couched within a prosodic hierarchy that allows domain skipping. Although the original proposal of the CG still does not assume recursivity (Vogel, 2008, 2009, 2010; see also Vigário, 2010), ${ }^{13}$ it has been argued that a prosodic hierarchy that contains the CG is not incompatible with domain recursion (Guzzo, 2018).

An additional possibility advanced in previous research is that BP clitics are prosodized recursively in the PWd, as in Brisolara (2008). This analysis, however, focused exclusively on pronominal clitics and was based on their variable behaviour with regard to vowel reduction in another southern variety of BP. The representation assigned to these clitics is identical to the one shown in Fig. 7. Although this analysis considers the potential effect of a variable phenomenon for clitic prosodization, it fails to account for the observation that pronominal clitics are different from unstressed monosyllabic prefixes with respect to vowel reduction: as previously discussed, while clitics undergo vowel reduction (albeit variably), the process is blocked in unstressed prefixes, unless they exhibit a specific phonotactic profile.

It thus seems that assigning (IIA-)BP clitics to either the CG or the PPh accounts for their phonological behaviour more adequately. The question that remains is whether pronominal and non-pronominal clitics are prosodized in the same domain or in separate domains. Considering the IIA-BP data for vowel reduction presented in the previous section, we propose that pronominal and non-pronominal clitics are prosodized in distinct domains in this variety.

As shown, vowel reduction is statistically more frequent in non-pronominal than in pronominal clitics. In this sense, pronominal clitics' behaviour is intermediary in comparison to the behaviour of unstressed monosyllabic prefixes, which do not allow vowel reduction, and non-pronominal clitics, where reduction is very frequent. The frequency of application of vowel reduction in unstressed monosyllables that attach rightward to a host can be represented with the following scale:

(11) Unstressed Prefixes $\ll$ Pronominal Clitics $<$ Non-Pronominal Clitics

13 The domain between the PWd and the PPh proposed by Vigário (2010), namely the Prosodic Word Group, does not play a specific role in clitic prosodization (Vigário, 2010: 485), unlike Vogel's composite group. 
Such differences in the frequency of application of vowel reduction suggest that pronominal clitics are prosodized in a lower prosodic domain than nonpronominal clitics. This implies that reduction in unstressed monosyllables is more frequent the higher they attach to their hosts. Given these considerations, we propose that non-pronominal clitics attach to the PPh (see Fig. 10), while pronominal clitics attach to the CG (see Fig. 11). Although the analysis of reduction frequency used data only for clitic $s e$, we assume that the representations in Figs. 10 and 11 are applicable to all pronominal and non-pronominal clitics in IIA-BP.

While these representations apply to IIA-BP clitics, it is unclear whether they can be extended to other varieties of BP. As previously mentioned, in the case of the BP varieties where vowel reduction in clitic position is obligatory, a prosodic analysis based solely on phonological arguments would have no principled reason to propose that pronominal and non-pronominal clitics are prosodized in different domains. On the other hand, other BP dialects exhibit variable vowel reduction in clitic position, in which case similar patterns to those observed in the IIA might be present. One such dialect is the dialect of Curitiba (state of Paraná), where vowel reduction is also variable in wordfinal and clitic position (e.g., Vieira, 2009; Limeira, 2013). However, analyses of the Curitiba dialect in general do not differentiate between pronominal and non-pronominal clitics (e.g., Limeira, 2013), which prevents the extension of our proposal for IIA-BP to such a dialect.

An analysis of variable vowel reduction in clitic forms that discriminates between pronominal and non-pronominal se was performed in the city of Pelotas (state of Rio Grande do Sul; Vieira, 2014). Pelotas, unlike the municipalities of
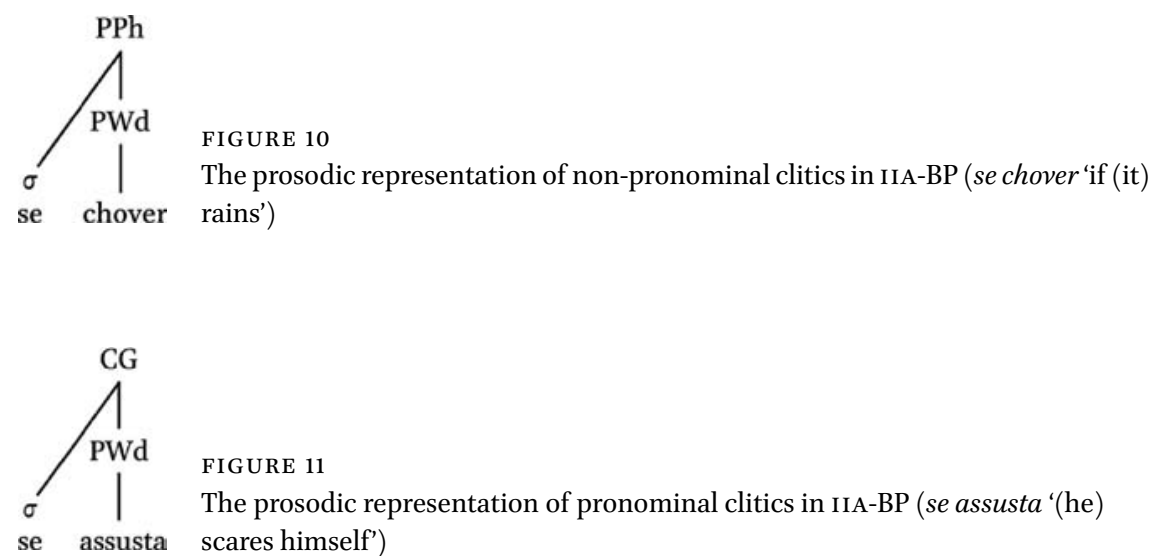

FIGURE 11

The prosodic representation of pronominal clitics in IIA-BP (se assusta '(he)

scares himself') 
the IIA, is not in a situation of language contact. As a result, the variation in vowel reduction observed in clitic position for this dialect is not due to the influence of the phonological system of another language. Vieira (2014), however, obtained similar proportions for both pronominal and non-pronominal $s e$. As will be argued in Section 5, IIA-BP speakers draw from Veneto the possibility of not reducing clitic vowels, which allows them to signal the distinction in prosodic representation between pronominal and non-pronominal clitics. The data from Pelotas seem to suggest that such a distinction in prosodic representation might be present only in IIA-BP. Data from other dialects where vowel reduction is variable in clitics should help arbitrate this issue. Since it is not within the scope of this paper to discuss clitic prosodization across varieties of BP, we leave the matter of whether other varieties also use two domains for the representation of clitic structures for future research.

Finally, it should be noted that the CG, similarly to the old clitic group, accounts for the prosodization of structures with compositional features, such as certain compounds and constructions with stressed affixes (Nespor and Vogel, 1986; Vogel, 2008, 2009, 2010). Thus, the proposal that structures containing pronominal clitics are assigned to the CG implies that such structures have compositional characteristics. A possible way to assess this issue is to examine whether clitic structures display compositional behaviour in the morphosyntax, which in turn would be an indication of their mapping as composite structures in the prosodic hierarchy. In the next section, we discuss the morphosyntactic behaviour of pronominal and non-pronominal clitics in order to examine whether such behaviour is consistent with their proposed prosodic representations.

Morphosyntactic Behaviour of Pronominal and Non-pronominal Clitics

One of the premises of prosodic phonology is that the mapping of morphosyntactic structures into prosodic structures is indirect (e.g., Selkirk, 1984, 1996, 2011; Klavans, 1985; Nespor and Vogel, 1986). In this sense, morphosyntactic structure is not visible to the application of phonological processes, which are instead constrained by the prosodic domains that result from syntax-phonology mapping. Therefore, analysing the morphosyntactic behaviour of a given linguistic construction as a predictor of the application of phonological processes is irrelevant under the framework of prosodic phonology. 
However, even though morphosyntactic behaviour does not determine the prosodic mapping of a given structure, it could provide evidence for the way in which such a structure is prosodically mapped. Specifically in the case of clitics, morphosyntactic behaviour could reveal whether a particular clitic construction is interpreted by the phonological component of the grammar as a composite structure. In this section, we examine how pronominal and nonpronominal clitics in BP select their hosts, whether or not they can be part of clitic strings, and whether or not they allow the insertion of other elements between themselves and their host. If a clitic is morphosyntactically dependent on its host, this could be an indication that the clitic is prosodically mapped into a composite structure. The data discussed in this section applies to $\mathrm{BP}$ in general and so can be extended to IIA-BP.

Pronominal and non-pronominal clitics in BP share a similarity: they are both proclitics. The case of non-pronominal clitics is quite clear: in BP, as in Romance languages in general, clitics corresponding to determiners, prepositions and conjunctions select a host to their right. In the case of pronominal clitics, BP is strikingly different from other varieties of Portuguese and closelyrelated Romance languages such as Spanish. While in other Romance languages enclisis is either the norm (such as in European Portuguese; see, e.g., Barbosa, 2000) or required by certain verb forms or moods (such as in Spanish and Italian; see, e.g., Belletti, 1999), in spoken BP enclisis is very rarely attested (see, e.g., Galves and Abaurre, 2002).

Apart from this similarity, pronominal and non-pronominal clitics differ in a number of ways. The first difference is that only non-pronominal clitics can form strings (see (12)). Unlike European Portuguese, in which strings of pronominal clitics are allowed (see, e.g., Bermúdez-Otero and Luís, 2009; 13a), BP avoids such strings through various strategies, such as using a null object (see $13 \mathrm{~b}$ ) or substituting one of the clitics for a full pronoun (see (13c); Farrell, 1990; Galves and Abaurre, 2002; Cyrino and Lopes, 2016). ${ }^{14}$ Note that, in (13c), the full pronoun is in postverbal position, following the canonical svo order for Portuguese. In the examples in (13), the arguments that can potentially be substituted by clitic forms are highlighted: those that would correspond to an accusative clitic are underlined while those that would correspond to a dative clitic are bolded.

14 Null objects in BP correspond to third-person accusative forms (see, e.g., Farrell, 1990; Cyrino and Lopes, 2016). The use of a full pronoun instead of a clitic can target all grammatical persons. In constructions with both a direct and an indirect object, if the direct object is not third-person, the construction that will be realized with a full pronoun is the indirect object. For example: *Ele me lhe dedurou $\rightarrow$ Ele me dedurou para ela 'He snitched on me (direct object) to her'. 
(12) a de que gosto é azul the of which (I) like.Prs is blue 'The one that I like is blue.'

(13) a. European Portuguese:

Eu compro opresente para ti $\rightarrow$ Eu to compro $\quad($ to $=$ te $+\underline{o})$

I buy.PRs the present for you

I buy the present for you.

b. Brazilian Portuguese:

Eu compro opresente para ti $\rightarrow$ Eu te compro $\underline{\emptyset}$

c. Brazilian Portuguese:

Eu compro o presente parati $\rightarrow$ Eu te compro ele

Non-pronominal and pronominal clitics in BP also differ with regard to host selection. While non-pronominal clitics can potentially attach to hosts of any word classes (14), pronominal clitics attach to a specific type of host, namely, the main verb of the clause (15; auxiliary verbs are italicized). ${ }^{15}$ This further explains why, in the example (13c), a full pronoun substituting a clitic form has to be in postverbal position: even if the full pronoun could occupy a preverbal position, it would never be selected as a host by the pronominal clitic ( ${ }^{*} \mathrm{Eu}$ te ele compro).

(14) Cansado de correr $_{w}$ cansado de festas ${ }_{n}$ cansado de tudo tired of running tired of parties tired of everything '(Someone is) tired of running, tired of parties, tired of everything.'
a. Eu me $\underline{\text { visto }}$
I REFL dress.PRS
'I dress myself.'
b. Eu tinha me vestido
I have.IMPERF REFL dressed
'I had dressed myself.'

15 A pronominal clitic may appear before the auxiliary verb only when it corresponds to a passive marker or an impersonal marker (e.g., Se deveria comer menos carne 'one should eat less meat'; Se deveria trabalhar menos 'one should work less'). Placing the clitic before the main verb is also possible in these contexts. We assume that, when the clitic precedes the auxiliary, its host is the auxiliary verb. 


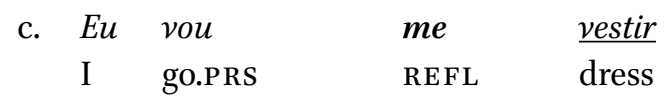

'I am going to dress myself.'

Furthermore, only non-pronominal clitics allow the insertion of other elements between themselves and their host (16). Pronominal clitics in BP cannot be separated from their verb hosts (17), unlike what is observed in certain European Portuguese constructions (e.g., Bermúdez-Otero and Luís, 2009). In (16) and (17), the inserted element is in bold.

a. Cansei de correr $\rightarrow$ Cansei de tanto correr (I) am tired of running (I) am tired of too.much running 'I am tired of running. I am tired of running too much.'

b. Cansei de falar $\rightarrow$ Cansei de te falar (I) am tired of speaking (I) am tired of you speaking 'I am tired of speaking. I am tired of speaking to you.'

(17) Eu me cansei $\rightarrow$ Eu me cansei tanto (cf. *Eume tanto cansei) I REFL tire.PST I REFL tire.PST too.much 'I tired myself. I tired myself very much.'

In sum, there are three main differences in morphosyntactic behaviour between non-pronominal and pronominal clitics in BP: (a) only non-pronominal clitics can form clitic strings, (b) pronominal clitics select a specific type of host, and (c) pronominal clitics can never be separated from their hosts. These differences show that pronominal clitics are morphosyntactically dependent on their hosts, while non-pronominal clitics are morphosyntactically freer. More importantly, these differences are consistent with two observations discussed above: (i) that assigning pronominal clitics to the CG implies that pronominal clitic + host constructions correspond to composite structures, and (ii) that the phonological behaviour of pronominal clitics with regard to vowel reduction is intermediary between the behaviour of unstressed monosyllabic prefixes and non-pronominal clitics.

Focusing on (i) first, the morphosyntactic behaviour of pronominal clitics supports the idea that they are mapped into the prosodic hierarchy as part of composite structures. The observation that pronominal clitics cannot be separated from their hosts is in indication that these clitics must be mapped to a prosodic domain where the construction that they form with their host will be 
interpreted as a composite structure. In this sense, similar to other composite structures such as word-word compounds (e.g., guarda-chuva 'umbrella', lit. 'keep-rain'), the configuration of pronominal clitic + host structures is fixed and cannot be broken by the insertion of other elements between their parts. The fact that only one clitic is allowed in pronominal clitic constructions further indicates that these constructions are compositional: in the BP grammar, there is only one slot for pronominal clitics in verb constructions. In other words, sequences of pronominal clitics would violate the requirement for pronominal clitics to have a verb host to their right. Constructions that might require two clitics are thus resolved via one of the strategies shown in (13).

Turning to (ii), the frequency of vowel reduction in pronominal $s e$ is consistent with the proposal that pronominal clitics are prosodized in the CG. As previously shown, pronominal se in IIA-BP exhibits vowel reduction less frequently than non-pronominal se, but more frequently than unstressed monosyllabic prefixes for which reduction is not phonotactically conditioned. This mirrors the observation that, with regard to syntactic independence, pronominal clitics are intermediary between unstressed prefixes (which do not occupy a terminal syntactic node) and non-pronominal clitics (which occupy a terminal syntactic node and are relatively independent from their prosodic hosts). While pronominal clitics may occupy a terminal syntactic node, their instantiation relies on the existence of a verb to their right.

At this point, it should be once again stressed that these morphosyntactic differences alone cannot be used to identify prosodic structure, since prosodic domains are the product of indirect mapping from syntax. Thus, we limit ourselves to examining whether the morphosyntactic behaviour of clitic structures is consistent with our proposal that one clitic type (pronominal) is prosodically mapped as part of a composite structure while the other one (non-pronominal) is not. Even though these morphosyntactic differences are observed across varieties of $\mathrm{BP}$, the analysis here proposed cannot be extended beyond IIA-BP: in other BP varieties, the phonological behaviour of pronominal and non-pronominal clitics appears to be identical, which suggests a single form of prosodization.

In summary, the morphosyntactic data discussed in this section is consistent with the observation that vowel reduction is less frequent in pronominal than in non-pronominal clitics, which in turn indicates that there are two separate prosodic representations for IIA-BP clitics. One question that arises is whether and to what extent non-linguistic factors impact the variation that reflects prosodization. Figure 3 suggests that age group has a statistical effect on the phenomenon, which was confirmed by the statistical model. Additionally, the difference in frequency of vowel reduction between pronominal and 
non-pronominal clitics gradually increases from the younger to the older age groups. As previously mentioned, the individuals in the older groups (especially those in the $71+$ yo group) are those who are fully bilingual and who reportedly use Veneto regularly. We propose that the difference in frequency of vowel reduction between pronominal and non-pronominal clitics results from contact between IIA-BP and Veneto: contact provides speakers with a way of signalling distinctions in prosodic representation by restricting the frequency at which reduction applies in clitic position. The next section further explores this proposal.

\section{The Role of Contact in Prosodic Representation}

In the previous sections, we showed that vowel reduction in IIA-BP is more frequent in non-pronominal than in pronominal $s e$, and we argued that these patterns of reduction indicate that pronominal and non-pronominal clitics have distinct prosodic representations. We also pointed out that the frequency at which vowel reduction applies lowers from one age group to the other (from younger to older). Additionally, as shown in Fig. 3, all age groups exhibit a higher rate of reduction with non-pronominal than pronominal clitics, but the difference between these clitic types is steeper for the two older age groups (the $71^{+}$yo group exhibits the largest difference). The speakers in the older age groups, particularly in the $71+$ yo group, are those who are fully bilingual in Portuguese and Veneto, and also those who use Veneto more frequently. This suggests that speakers' prosodic representations are affected by contact with Veneto.

Language contact may impact speakers' prosodic representations in two ways: (i) speakers may transfer prosodic structures from Language $X$ into Language $Y$; and (ii) speakers may rely on a phenomenon from Language $X$ to signal specific prosodic representations in Language Y. Possibility (i) has been shown to apply particularly in contexts of second language acquisition: for example, production errors involving morpheme suppliance are often the result of an incompatibility of prosodic representations between first and second language, not the absence of the relevant syntactic features in the learners' first language (Goad et al., 2003; Goad and White, 2006, 2008). With respect to possibility (ii), it has been shown that speakers in contact situations often employ processes from one language in the other (see, e.g., Aikhenvald, 2002; Corrigan, 2010), but the extent to which prosodic representations constrain the use of such processes has not been extensively explored in the literature. 
In this section, we will argue that the case of clitics in IIA-BP conforms to (ii). Before exploring this possibility, we will examine the phonological and morphosyntactic behaviour of clitics in Veneto, in order to demonstrate that possibility (i) does not apply to the data under analysis (i.e., there is no evidence for distinct prosodic representations for pronominal and non-pronominal clitics in Veneto). The Veneto data that are discussed in this section apply both to IIA-Veneto and the Veneto varieties spoken in Northern Italy.

As mentioned above, a possible explanation for the difference between IIA$\mathrm{BP}$ and standard BP with respect to vowel reduction in clitic position is that IIA-BP speakers are using the Veneto representations for clitic structures. In this sense, the difference in frequency of vowel reduction between pronominal and non-pronominal clitics in IIA-BP would be a consequence of the way in which these clitics are prosodized in Veneto. However, Veneto pronominal and non-pronominal clitics have a similar phonological behaviour. For example, neither pronominal nor non-pronominal clitics exhibiting an upper-mid vowel undergo vowel reduction (e.g., Zamboni, 1974; Frosi and Mioranza, 1983), as the examples in (18) show.

(18) Pronominal clitics in Veneto:

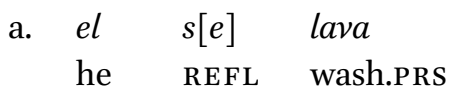

'He washes himself.'

b. el $m[e]$ ga dito

he me have.prs told

'He has told me.'

Non-pronominal clitics in Veneto:

c. $s[e]$ la piova la vien

if the rain it come.Prs

'If the rain comes.'

d. $d[e] \quad$ Cassía

from Caxias

'From Caxias (city in the IIA).'

The same is true for unstressed PWd-final vowels, which do not undergo reduction or raising in Veneto. In the case of final upper-mid vowels, raising to high implies a difference in meaning, as word-final morpheme $-i$ is used to signal 
pluralization in masculine nouns (Zamboni, 1974; Frosi and Mioranza, 1983; see also Walker, 2005; see (19)).

Neither pronominal nor non-pronominal clitics in Veneto affect the realization of the initial segment of the host word (in the case of pronominal and non-pronominal proclitics) or the final segment of the host word (in the case of pronominal enclitics). This indicates that the nature of the prosodic boundaries projected by the clitic is identical for both pronominal and nonpronominal clitics. Additionally, both pronominal and non-pronominal clitics undergo juncture processes in clitic strings, particularly when the second clitic of the string starts with a vowel or $/ 1 /$, which may be variably deleted (e.g., Belloni, 2009), as illustrated in (20) (the examples are adapted from Belloni, 2009).

(20) Juncture targeting pronominal clitics in Veneto:
a. Te lo porto
you it (I) bring.PRs tomorrow
doman $\rightarrow \mathrm{Te}$
o porto doman
'I will bring this to you tomorrow.'
b. Ghe lo digo senpre $\rightarrow$ Ghe o digo senpre them it (I) tell.Prs always

'I always tell them this.'

Juncture targeting non-pronominal clitics in Veneto:
c. Mi go parlá co el dotor $\rightarrow$ mi go parláco l dotor
I have.PRs spoken with the doctor
'I spoke with the doctor.'
d. Ciapa la sécia de le naranse $\rightarrow$ Ciapa la sécia de e naranse take.IMP the bucket of the oranges
'Take the bucket with the oranges.'

With regard to morphosyntactic behaviour, Veneto pronominal and nonpronominal clitics exhibit a few differences: while non-pronominal clitics are invariably proclitics, pronominal clitics can be found in both proclitic and enclitic position, similarly to what is observed in other Romance languages such as Spanish and Italian. In Veneto, pronominal clitics are enclitic in constructions with infinitive verbs (21a) and imperatives (21b). 
(21) Infinitive constructions in Veneto:

$\begin{array}{llll}\text { a. } & \text { Ndemo } & \text { magnar lo } \\ \text { go.1PL.IMP } & \text { eat } & \text { it } \\ \text { 'Let's eat it.' } & & \end{array}$

Imperatives in Veneto:

$\begin{array}{ll}\text { b. Magna } & \text { lo } \\ \text { eat.IMP } & \text { it }\end{array}$

'Eat it!'

Unlike in BP, both pronominal and non-pronominal clitics in Veneto can form clitic strings (see 20), which is also observed in other Romance languages, as previously mentioned. With respect to host selection, pronominal clitics in Veneto select a verb as their host, but, unlike in BP, in complex constructions the clitic precedes the auxiliary verb (22).

$\begin{array}{lll}\text { (22) a. } & \text { El me ga } & \text { dito } \\ & \text { he me have.Prs } & \text { told } \\ \text { 'He has told me.' } & \\ \text { b. } & \text { Mi me go } & \text { spaventá } \\ \text { I REFL have.Prs } & \text { scared } \\ & \text { 'I got scared.' }\end{array}$

These data show that pronominal and non-pronominal clitics in Veneto exhibit certain morphosyntactic differences, although, unlike in BP, they do not provide support for the proposal that one clitic type forms a composite structure with its host. Pronominal clitics in Veneto select the entire verb structure as their host when they are in proclitic position, and the main verb of the construction when they are in enclitic position, which suggests that the prosodic domain which they form with their host is not constrained by the nature of the clitic, although it may be affected by its position in the syntactic structure. ${ }^{16}$

Examination of the phonological behaviour of Veneto clitic structures does not support the idea that pronominal and non-pronominal clitics in this language are represented in separate prosodic domains. This indicates that the prosodic structure of Veneto clitics cannot be a source for the representation of pronominal and non-pronominal clitics in IIA-BP. Additionally, the fact that IIA-BP speakers' productions conform to the patterns of clitic placement and

16 It has been proposed, for languages that exhibit both proclisis and enclisis, that the prosodic representation of proclitics and enclitics is different (see, e.g., Vigário, 2003, for European Portuguese). 
host selection observed in standard BP is an indication that the mapping of clitic structures, for these speakers, follows the constraints that regulate clitic mapping in BP.

Given this scenario, contact with Veneto provides IIA-BP speakers not with an alternative prosodic representation, but instead with the possibility of preserving upper mid vowels in clitic position. This alternative way of producing clitic vowels is used by these speakers as a way of signalling prosodic distinctions between pronominal and non-pronominal clitics in their BP variety. Specifically, preservation of the upper mid vowel signals that the clitic structure is prosodized in a lower domain, while reduction signals that the structure is prosodized in a higher domain. Preservation of the upper mid vowel thus indicates that the clitic is more dependent on its host and shares some structural properties with the language's prefixes.

The alternation between upper mid and high vowels in clitic position to signal prosodic distinctions is observed more systematically in the productions of the older age groups because the speakers in these groups are those who are more proficient in Veneto and use the language regularly. In the two younger age groups, vowel reduction is also more frequent in non-pronominal clitics (Fig. 3); however, in these groups, vowel reduction in clitic position is predominant (i.e., there is more reduction than non-reduction overall), and the difference between pronominal and non-pronominal clitics with regard to vowel reduction is not as striking as it is for the older age groups, in particular for the $71+$ yo group. This suggests that although younger groups should also be able to signal prosodic differences through vowel reduction patterns, reduction in clitic position (regardless of clitic type) is becoming the norm among these speakers, in line with what is observed in standard BP.

\section{Conclusion}

In this paper, we explored the extent to which distinctions in prosodic representation affect the frequency at which a variable phenomenon (vowel reduction) applies in pronominal and non-pronominal clitic se in IIA-BP, a variety of Brazilian Portuguese in contact with Veneto. We showed that reduction is statistically more frequent in non-pronominal than pronominal $s e$, which indicates that, given IIA-BP phonology, pronominal clitics are represented in a lower prosodic domain relative to non-pronominal clitics. Specifically, pronominal clitics are prosodized in the composite group, while non-pronominal clitics are prosodized in the phonological phrase.

Importantly, our findings indicate that IIA-BP speakers use vowel reduction as a way to signal differences in prosodic representation. This distinction 
between two prosodic representations for clitic structures is only possible due to contact with Veneto, where upper mid vowels in clitic position are not reduced to high, unlike what is observed in standard BP. It is not the case, however, that contact with Veneto provides speakers with an additional prosodic representation for clitic structures, as we have found no phonological evidence to support the idea that pronominal and non-pronominal clitics in Veneto are prosodized in separate domains. What we have proposed instead is that contact with Veneto influences the application of vowel reduction in clitic position in IIA-BP, and the frequency at which reduction applies reflects speakers' prosodic representations for clitic structures. Further research is required to verify whether Veneto phonology constrains the prosodic representation of other linguistic constructions in IIA-BP. More research is also necessary to examine whether the proposed prosodic structures for pronominal and nonpronominal clitics in IIA-BP are applicable to clitic structures in other dialects of BP, particularly those where there is variable vowel reduction in clitic position.

Finally, we have also showed that speakers who are fully bilingual in Portuguese and Veneto and report using Veneto regularly are those who exhibit the largest difference in vowel reduction between pronominal and nonpronominal clitics. These speakers belong particularly to the older age group (71+ yo), even though the other three age groups controlled in the analysis exhibit similar trends. The results are thus consistent with the idea that those who are more proficient in Veneto will rely more strongly on a feature of Veneto phonology (i.e., upper mid vowel preservation in clitic position) to signal prosodic distinctions in IIA-BP.

\section{Acknowledgements}

We are grateful to Elisa Battisti and Heather Goad for their input on several aspects of this study, as well as to two anonymous reviewers for their helpful comments. We also thank Elisa Battisti for granting us access to the interviews of the BDSer database.

\section{References}

Abaurre, Maria Bernadete. 1996. Acento frasal e processos fonológicos segmentais [Phrasal stress and segmental phonological processes]. Letras de Hoje 31(2): 41-50. Aikhenvald, Alexandra Y. 2002. Language contact in Amazonia. Oxford: Oxford University Press. 
Anderson, Stephen R. 2005. Aspects of the theory of clitics. Oxford: Oxford University Press.

Barbosa, Pilar. 2000. Clitics: A window into the null subject property. In João Costa (ed.) Portuguese syntax: New comparative studies, 31-93. Oxford: Oxford University Press.

Battisti, Elisa. 1993. Elevação das vogais médias pretônicas em sílaba inicial de vocábulo na fala gaúcha [Raising of pretonic mid vowels in word-initial syllable in southern Brazil]. MA thesis, Universidade Federal do Rio Grande do Sul, Brazil.

Battisti, Elisa. 2004. Variação linguística como prática social: Análise quantitativa e qualitativa da realização da vibrante no português em contato com italiano. [Language variation as social practice: Quantitative and qualitative analysis of the rhotic in a Portuguese variety in contact with Italian]. Lingua (gem) 1(2): 107-124.

Battisti, Elisa, Adalberto Dornelles Filho, João Inácio Pires Lucas, and Nínive Magdiel Peter Bovo. 2007. Palatalização das oclusivas alveolares e a rede social dos informantes. [Palatalization of alveolar stops and informants' social network]. Revista Virtual de Estudos da Linguagem 5(9): 1-29.

Battisti, Elisa and Cristiane Lembi. 2004. BDSer: Corpus linguístico como acervo de experiências pessoais [BDSer: linguistic corpus as a collection of personal experiences]. Métis: história \& cultura 3(50): 61-79.

Belletti, Adriana. 1999. Italian/Romance clitics: Structure and derivation. In Henk van Riemsdijk (ed.) Clitics in the languages of Europe, 543-580. Berlin: Mouton de Gruyter.

Belloni, Silvano. 2009. Grammatica veneta [A grammar of Veneto]. Padova: Esedra.

Bermúdez-Otero, Ricardo and Ana R. Luís. 2009. Cyclic domains and prosodic spans in the phonology of European Portuguese functional morphs. In Workshop on the Division of Labour between Morphology and Phonology and Fourth Meeting of the Network 'Core Mechanisms of Exponence', Meertens Instituut, Amsterdam.

Bisol, Leda. 1981. Harmonia vocálica: Uma regra variável [Vowel harmony: A variable rule]. PhD dissertation, Universidade Federal do Rio de Janeiro, Brazil.

Bisol, Leda. 1991. Palatalization and its variable restriction. International Journal of Sociology of Language 89: 107-124.

Bisol, Leda. 200o. O clítico e seu status prosódico. [Clitics and their prosodic status]. Revista de Estudos da Linguagem 9(1): 5-30.

Bisol, Leda. 2003. Sandhi in Brazilian Portuguese. Probus 15: 177-200.

Bisol, Leda. 2005. O clítico e seu hospedeiro. [Clitics and their hosts]. Letras de Hoje 40(3): 163-184.

Bisol, Leda. 2009. O alçamento da pretônica sem motivação aparente. [Unmotivated raising of pretonic mid vowels]. In Leda Bisol and Gisela Collischonn (eds.) Português do sul do Brasil: Variação fonológica. [Southern Brazilian Portuguese: Phonological variation]. Porto Alegre: EDIPUCRs. 
Boersma, Paul and David Weenink. 2020. Praat: Doing phonetics by computer [Computer program]. Version 6.1.o9.

Brisolara, Luciene Bassols. 2008. Os clíticos pronominais do português brasileiro e sua prosodização. [Pronominal clitics and their prosodization]. PhD dissertation, Pontifícia Universidade Católica do Rio Grande do Sul, Brazil.

Câmara, Joaquim Mattoso Jr. 1970. Estrutura da língua portuguesa [The structure of the Portuguese language]. Petrópolis: Vozes.

Carpenter, Bob, Andrew Gelman, Matthew D. Hoffman, Daniel Lee, Ben Goodrich, Michael Betancourt, Marcus Brubaker, Jiqiang Guo, Peter Li, and Allen Riddell. Stan: A probabilistic programming language. Journal of Statistical Software 76(1): $1-32$.

Corrigan, Karen P. 2010. Language contact and grammatical theory. In Raymond Hickey (ed.) The handbook of language contact, 106-127. Malden, MA: Blackwell.

Cyrino, Sonia and Ruth Lopes. 2016. Null objects are ellipsis in Brazilian Portuguese. The Linguistic Review 33(4): 483-502.

De Boni, Luís A. and Rovílio Costa. 1979. Os italianos do Rio Grande do Sul. [The Italians from Rio Grande do Sul]. Porto Alegre: Escola Superior de Teologia São Lourenço de Brindes. Caxias do Sul: Educs.

Farrell, Patrick. 1990. Null objects in Brazilian Portuguese. Natural Language and Linguistic Theory 8: 325-346.

Frosi, Vitalina M. and Ciro Mioranza. 1983. Dialetos italianos: Um perfil linguístico dos ítalo-brasileiros do Nordeste do Rio Grande do Sul. [Italian dialects: A linguistic profile of the Italian-Brazilians in the Northeast of Rio Grande do Sul]. Caxias do Sul, Brazil: EDUCs.

Frosi, Vitalina M. and Ciro Mioranza. 2009. Imigração italiana no nordeste do Rio Grande do Sul. [Italian immigration in the northeast of Rio Grande do Sul]. 2nd edition. Caxias do Sul: EDUCs.

Galves, Charlotte and Maria Bernadete Abaurre. 2002. Os clíticos no português brasileiro: Elementos para uma abordagem sintático-fonológica. [Brazilian Portuguese clitics: elements for an analysis at the syntax-phonology interface]. In Ataliba de Castilho and Margarida Basílio (eds.) Gramática do português falado, v.4: Estudos descritivos. [A grammar of spoken Portuguese: Descriptive studies]. 2nd edition. Campinas: Editora da Unicamp.

Gayer, Juliana Escalier Ludwig. 2014. Uma análise da elisão e da degeminação com base em restrições. [A constraint-based analysis of elision and degemination]. $\mathrm{PhD}$ dissertation, Universidade Federal do Rio Grande do Sul, Brazil.

Goad, Heather and Lydia White. 2006. Ultimate attainment in interlanguage grammars: A prosodic approach. Second Language Research 22: 243-268.

Goad, Heather and Lydia White. 2008. Prosodic structure and the representation of L2 functional morphology: A nativist approach. Lingua 118: 577-594. 
Goad, Heather, Lydia White, and Jeffrey Steele. 2003. Missing inflection in L2 acquisition: Defective syntax or L1-constrained prosodic representations? Canadian Journal of Linguistics 48(3/4): 243-263.

Guzzo, Natália Brambatti. 2010. A elevação da vogal media anterior átona em Flores da Cunha (RS) [Raising of the mid front vowel in the speech of Flores da Cunha (RS)]. MA thesis, Universidade de Caxias do Sul, Brazil.

Guzzo, Natália Brambatti. 2012. Elevação de /e/ e apagamento vocálico : O comportamento dos clíticos [Raising of /e/ and vowel deletion: The behaviour of clitics]. Cadernos do IL 44: 185-202.

Guzzo, Natália Brambatti. 2018. The prosodic representation of composite structures in Brazilian Portuguese. Journal of Linguistics 54(4): 683-720.

Hayes, Bruce. 1989. The prosodic hierarchy in meter. In Paul Kiparsky and Gilbert Youmans (eds.) Rhythm and meter, 201-26o. Orlando: Academic Press.

Inkelas, Sharon. 1990. Prosodic constituency in the lexicon. New York: Garland Press.

Klavans, Judith L. 1985. The independence of syntax and phonology in cliticization. Language 61(1): 95-120.

Leite, Yonne and Dinah Callou. 2002. Como falam os brasileiros [How Brazilians speak]. Rio de Janeiro: Zahar.

Limeira, Larissa. 2013. O não-alçamento das vogais médias na fala de Curitiba sob a perspectiva da sociolinguística quantitativa [Non-raising of mid vowels in the speech of Curitiba under the perspective of quantitative sociolinguistics]. MA thesis, Universidade Federal do Rio Grande do Sul, Brazil.

Massini-Cagliari, Gladis. 1992. Acento e ritmo. [Stress and rhythm]. São Paulo: Contexto.

Mateus, Maria Helena and Ernesto d'Andrade. 2000. The phonology of Portuguese. Oxford: Oxford University Press.

Mauri, Cristina. 2008. Palatalização das oclusivas alveolares e práticas sociais em capelas de Forqueta, Caxias do Sul (RS). [Palatalization of alveolar stops and social practices in church communities in Forqueta, Caxias do Sul]. MA thesis, Universidade de Caxias do Sul, Brazil.

Nespor, Marina and Irene Vogel. 1986. Prosodic phonology. Dordrecht: Foris.

Oliveira, Marco Antônio de. 1992. Aspectos da difusão lexical [Aspects of lexical diffusion]. Revista de Estudos da Linguagem 1: 31-41.

Peperkamp, Sharon. 1997. Prosodic words. PhD dissertation, Holland Academic Graphics, University of Amsterdam, The Hague.

R Development Core Team. 2018. R: A language and environment for statistical computing. Vienna, Austria.

Roveda, Suzana Damiani. 1998. Elevação da vogal média átona final em comunidades bilíngues: português e italiano. [Raising of the unstressed final mid vowel in bilingual communities: Portuguese and Italian]. MA thesis, Pontifícia Universidade Católica do Rio Grande do Sul, Brazil. 
Schwindt, Luiz Carlos. 2001. O prefixo no português brasileiro: Análise prosódica e lexical [Prefixes in Brazilian Portuguese: A lexical and prosodic analysis]. DELTA 17(2): 175-207.

Schwindt, Luiz Carlos. 2008. Revisitando o estatuto prosódico e morfológico de palavras prefixadas do $\mathrm{PB}$ em uma perspectiva de restrições [Revising the prosodic status and the morphological status of prefixed words in Brazilian Portuguese through a constraint-based approach]. Alfa 52(2): 391-404.

Selkirk, Elisabeth. 1984. Phonology and syntax: The relation between sound and structure. Cambridge, MA: MIT Press.

Selkirk, Elisabeth. 1996. The prosodic structure of function words. In James L. Morgan and Katherine Demuth (eds.), Signal to syntax: Bootstrapping from speech to grammar in early acquisition, 187-214. Mahwah, NJ: Lawrence Erlbaum Associates.

Selkirk, Elisabeth. 2011. The syntax-phonology interface. In John Goldsmith, Jason Riggle, and Alan Yu (eds.), The handbook of phonological theory, 435-483. Oxford: Blackwell.

Simioni, Taíse. 2008. O clítico e seu lugar na estrutura prosódica em português brasileiro [The clitic and its place in the prosodic hierarchy in Brazilian Portuguese]. Alfa 52(2): $431-446$.

Spencer, Andrew and Ana R. Luís. 2012. Clitics: An introduction. Cambridge: Cambridge University Press.

Souza, José Otávio Catafesto de. 2008. O povoamento indígena na região de Antônio Prado [Indigenous peoples in the area of Antônio Prado]. In Onira Baccarin, Dirce Brambatti Guzzo, and Vera Lucia Maciel Barroso (eds.), Raízes de Antônio Prado, 38-47. Porto Alegre: EST.

Tenani, Luciani Ester. 2002. Domínios prosódicos no português [Prosodic domains in Portuguese]. PhD dissertation, Universidade Estadual de Campinas, Brazil.

Toneli, Priscila Marques. 2014. A palavra prosódica no português brasileiro [The prosodic word in Brazilian Portuguese]. PhD dissertation, Universidade Estadual de Campinas, Brazil.

Tomiello, Marciana. 2005. A variação do ditongo nasal tônico -ão como prática social no português de São Marcos/RS. [Variation in the realization of the nasal diphthong -ão as social practice in the Portuguese variety of São Marcos/RS]. MA thesis, Universidade de Caxias do Sul, Brazil.

Vieira, Maria José Blaskovski. 2002. As vogais médias postônicas: Uma análise variacionista. [Post-tonic mid vowels: a variationist analysis]. In Leda Bisol and Cláudia Brescancini (eds.) Fonologia e variação: Recortes do português brasileiro. [Phonology and variation: Approaches to Brazilian Portuguese]. Porto Alegre, Brasil: EDIPUCRs.

Vieira, Maria José Blaskovski. 2009. As vogais médias átonas nas três capitais do sul do país [Unstressed mid vowels in the three capital cities of Southern Brazil]. In Leda Bisol and Gisela Collischonn (eds.) Português do Sul do Brasil: Variação fonológica 
[Portuguese in Southern Brazil: Phonological variation]. Porto Alegre, Brazil: EDIPUCRS.

Vieira, Maria José Blaskovski. 2014. Produção e percepção de vogais em clíticos [Production and perception of vowels in clitics]. Proceedings of the XVII Congreso Internacional de la Asociación De Lingüística y Filología de América Latina (ALFAL 2014), João Pessoa, Brazil.

Vigário, Marina. 2003. The prosodic word in European Portuguese, vol. 6. Berlin: Walter de Gruyter.

Vigário, Marina. 2010. Prosodic structure between the prosodic word and the phonological phrase: Recursive nodes or an independent domain? The Linguistic Review 27: 485-530.

Vogel, Irene. 2008. The morphology-phonology interface: Isolating to polysynthetic languages. Acta Linguistica Hungarica 55(1): 205-226.

Vogel, Irene. 2009. The status of the clitic group. In Janet Grijzenhout and Baris Kabak (eds.), Phonological domains: Universals and deviations, 15-46. Berlin: Mouton de Gruyter.

Vogel, Irene. 2010. The phonology of compounds. In Sergio Scalise and Irene Vogel (eds.), Crossdisciplinary issues in compounding, 145-163. Amsterdam: John Benjamins.

Walker, Rachel. 2005. Weak triggers in vowel harmony. Natural Language and Linguistic Theory 23: 917-989.

Wetzels, W. Leo. 1992. Mid vowel neutralization in Brazilian Portuguese. Cadernos de Estudos Linguísticos 23: 19-55.

Zamboni, Alberto. 1974. I dialetti del Veneto [Dialects of Veneto]. Pisa: Pacini.

Zwicky, Arnold M. 1977. On clitics. Bloomington: Indiana University Linguistics Club.

Zwicky, Arnold M. 1985. Clitics and particles. Language 61(2): 283-305. 


\section{Appendix}

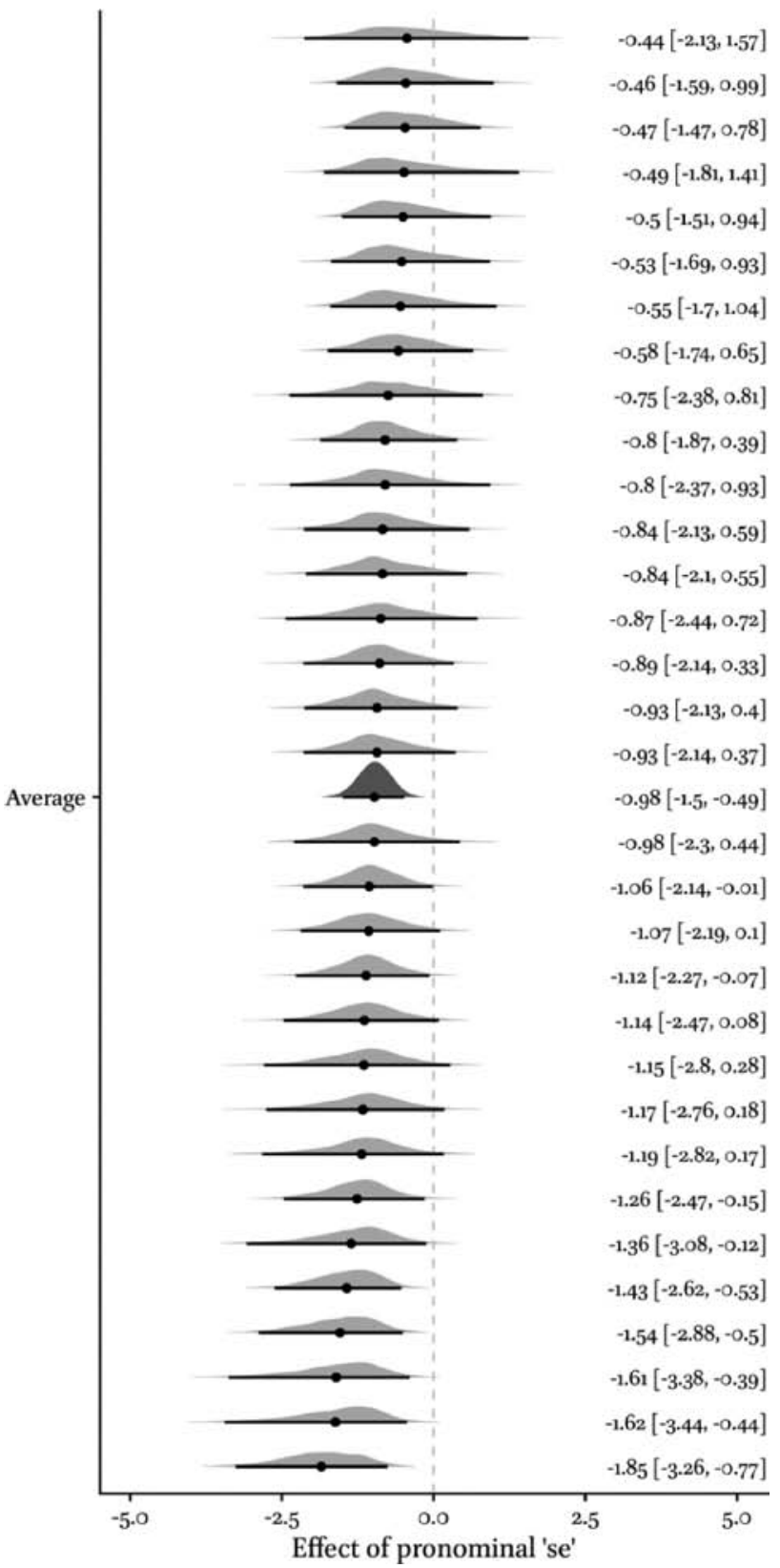

FIGURE 12 By-participant random effects of TYPESE, associated means, and 95\% HDI. The posterior distributions of all participants have negative means, indicating speakers consistently disfavour reduction in pronominal se. Average posterior distribution is also shown (i.e., fixed effect of Pronominal ' $s e$ ' in Fig. 4) 